\title{
Fronteiras de um mundo insólito: olhares estrangeiros sobre uma varanda híbrida
}

\author{
Frontiers of an unusual world: foreign views from a hybrid balcony
}

\author{
LUCIANA MORAIS DA SILVA \\ FLAVIO GARCÍA \\ Universidade do Estado do Rio de Janeiro - Rio de Janeiro - Rio de Janeiro - Brasil
}

-

\begin{abstract}
Resumo: O trânsito entre nações e os conflitos por ele gerados são diálogos comuns na atualidade. Em Moçambique, o processo de configuração de nação/nacionalidade não ocorre de modo diferente. Ali, tem-se, porém, um agravante denunciado por Mia Couto - tanto em sua ficção, quanto em seus textos de opinião -, que se refere a diversidades de origem, até mesmo àquelas de foro linguístico - nesse caso, além da multiplicidade de línguas aborígenes, verifica-se, ainda, uma intravariedade na realização da língua portuguesa, que o escritor explora em suas "brincriações". Nessa perspectiva, pode-se ler $A$ varanda do frangipani, de Mia Couto, à luz dos conceitos de hibridismo, fronteiras e trânsitos - formação constitutiva do caráter de ruptura da obra, devido à irrupção do insólito ficcional, no campo fronteiriço da cultura. Mia Couto exercita uma escrita contra-hegemônica, sustentada no jogo intercambiante do olhar quem, de onde, para onde, com que intenção, com que estratos de formação sociocultural olha e o que olha.
\end{abstract}

Palavras-chave: Insólito Ficcional; Personagens; Hibridismo; Fronteiras; Trânsitos

\begin{abstract}
The movement between nations and the conflicts it generates are common themes nowadays. In Mozambique, the process of configuration of nation/nationality is not different. There is, however, an aggravation of such process as pointed out by Mia Couto in his fiction and in his opinion texts: the diversity of origin and the linguistic diversity. Aboriginal languages, and varieties of the Portuguese language, which the writer explores with great skill in his "brincriações". From this perspective Mia Couto, A varanda do frangipani, can be read in the light of the concepts of hybridism, borders and transit as the constitutive character of rupture of his work, due to the eruption of the Fictional Uncommon and as a reference for the observation of the "inside" and "outside" elements in the field of hybrid culture. Mia Couto exercises a counter-hegemonic written experience, sustained by the game of interchangeable views - who, where, where to, with what intention, and from what socio-cultural ackground one observes and is observed.
\end{abstract}

Keywords: Fictional Uncommon; Characters; Hybridism; Borders; Transits

- Você quem é?

- Sou seu tradutor.

- Eu posso falar e entender. Problema não é a

língua. $\mathrm{O}$ que eu não entendo é este mundo daqui.

(COUTO, 2005a, p. 40 - grifo nosso)

Todo percurso por fronteiras, físicas ou não, implica mergulhos em espaços diversos - tanto no sentido de diferentes, quanto no de múltiplos -, que se cruzam nas margens da relação do homem com o seu quotidiano - experienciado de fato ou imaginariamente. A varanda do frangipani, do escritor mo- çambicano Mia Couto, trata de universos fronteiriços da cultura, abordando, no plano ficcional, processos de constituição do próprio homem - ser da terra, da nação, do mundo -, mosaico do universo que o cerca e tradutor - em sentido lato - das instâncias que o (con)formam. 
A obra de Mia Couto está (de)marcada por uma periodização que a localiza, genericamente, no que se vem convencionando rotular de pós-guerra - no caso de África, independentemente de se referir aos estados que tiveram sua origem nas colônias portuguesas ou não, pode-se, a despeito das divergências verificadas contemporaneamente, falar-se, ainda, nesse caso, em período pós-colonial -, e representa, via de regra, os momentos pós-libertação vividos pelo povo moçambicano - e, mesmo, em muitas vezes, angolano, como o próprio autor explicita em variados textos de opinião por ele já publicados - Pensatempos (2005); E Se Obama Fosse Africano? E Outras Interinvenções (2009); Pensageiro frequente (2010). Sua obra se constrói com base no gerenciamento de imagens advindas do ontem - lugar da memória, das tradições (não se pode deixar de tomar muito cuidado com as "opiniões" que o autor tem sobre a tradição, expressas sobejamente em seus textos pretensamente não ficcionais) -, que, resgatadas ou (re)inventadas, atuam no hoje, dando sentido a um conceito histórico de ser, ainda que, assumidamente, mosaico e híbrido.

Mia Couto declara-se, em Pensatempos, ele mesmo, um ser de fronteira, tendo, enquanto escritor, um papel mosaico, não apenas por conviver com a diversidade, ao desenvolver suas personagens, mas, também, pela sua configuração pessoal - ancestralidade e formação. Maria Fernanda Afonso, ao tratar dos processos de formação do conto moçambicano, percorre a obra do autor e discute suas narrativas, afirmando que:

Ao sonhar com a infância, Mia Couto recupera a beleza das imagens míticas que lhe deram a conhecer o mundo, a perfeição de um cosmos dilatado pela imaginação e pela memória. Indefinido, na distância de um tempo íntimo, mas aprimorado pela imaginação, o passado rememorado suscita o futuro da criação literária do autor.

[...] num abandono às sensações vindas do inconsciente, aos ecos de um passado inesquecível mas desaparecido, Mia Couto procura recriá-los, evocando a magia da sua própria infância. Neste apelo da infância, a escrita revela um desafio: partilhar a arte encantatória dos griots. (2004, p. 289 - grifo do original)

O processo de formação do escritor Mia Couto ocorre, portanto, já em suas origens, constituído pela sua herança portuguesa, mas também, contaminado pelo contato com os "do outro lado da rua: os indianos, os pretos, os mulatos chineses" (COUTO, 2002), que o ajudaram a encontrar(-se com) a mestiçagem (Cf. COUTO, 2002), ou seja, com aqueles que, semelhantemente a ele, trocaram identidades, formando novas e heterogêneas, permeadas pela multiplicidade de traços transitórios (Cf.
CANCLINI, 2008, p.XXIII). Mia Couto, discorrendo a respeito da constituição do ser escritor - não apenas do sujeito, como escritor, mas das funções social, política, cultural, artística, literária etc. do escritor, enquanto papel desempenhado no mundo em que vive -, explicita seus posicionamentos diante das identidades destes que pretendem trazer o real à ficção, e, assim, em $E$ se Obama fosse africano? E Outras Interinvenções, observa que "há tantas Áfricas quantos escritores, e todos eles estão reinventando continentes dentro de si mesmos" (2009, p. 25).

A assunção autoral de "reinventar continentes dentro de si mesmos" corrobora uma tomada de posição do artista, que se inventa - quer produtor desses espaços (continentes, no mais das vezes, mas, ainda, conteúdos, em outras delas), quer produto deles -, como muitos, em um - o que, física e empiricamente, ele pode, na sua condição humana de "ser", ser -, porque composto de muitas identidades, derivadas de sua origem - filho de pais portugueses - e formação - educado conforme padrões europeus - múltiplas e com matizes diversos marcadas pelo branco-euro-centrista da ancestralidade e pela afromoçambicanidade do lugar de nascença e criação. $\mathrm{O}$ autor - Mia Couto, em particular, ou todo e qualquer autor, coletivamente - constitui-se, dessa maneira, tradutor, "um viajante de identidades, um contrabandista de almas" (COUTO, 2005, p. 59).

A tradução, reivindicada pelo escritor e mimeticamente "representada" em sua ficção, só ganha concretude a partir do plano básico do signo linguístico, cuja "linguagem" são as várias línguas de expressão nacional. Essa tradução - transposição do linguístico para o semiológico; da língua, em seu uso quotidiano, para a língua literária, em seu emprego artístico -, se dá através de processos de recuperação e assimilação de elementos diversos, unindo fronteiras culturais, sociais, étnicas; continentais, nacionais, regionais; etc. ou, como ressalva Mia Couto: "um homem não é uma margem que apenas existe de um ou outro lado. Um homem é uma ponte ligando as diversas margens" (2005, p. 91).

As diversas margens, a que se refere o autor, revelam-se pelas sendas híbridas de sua constituição, não apenas nos escritores moçambicanos, propriamente, mas na perspectiva de que "Em todos os continentes, cada homem é uma nação feita de diversas nações" (COUTO, 2009, p. 25). Assim, é, pois, nessa concepção, trabalhando com a ideia de um processo de tradução, no qual as fronteiras se desestabilizam e se integram em uma composição mosaica, que se podem observar as diversas margens da "literatura do insólito" em Mia Couto, com os olhos voltados para uma escrita composta pelas diferenças. Conforme Homi Bhabha, em O local da cultura: 
O trabalho fronteiriço da cultura exige um encontro com "o novo" que não seja parte do continuum de passado e presente. Ele cria uma ideia do novo como ato insurgente de tradução cultural. Essa arte não apenas retoma o passado como causa social ou precedente estético; ela renova o passado, refigurando-o como um "entre-lugar" contingente, que inova e interrompe a atuação do presente. (2003, p. 27)

O passado, caracterizado pelo pesquisador como o “"entre-lugar' contingente", revela profundas raízes, que se amalgamaram durante anos. Em África, bem como na América Latina, os primeiros processos de trocas culturais se deram, hegemonicamente, através da assimilação, ou seja, da imposição da cultura do colonizador ao colonizado. Entretanto, a tradução de que fala Bhabha não é um processo estático, mas bastante fluido, que pode ser explicado pelas palavras de Stuart Hall, em Da Diáspora:

a cultura não é apenas uma viagem de redescoberta, uma viagem de retorno. Não é uma 'arqueologia'. A cultura é uma produção. Tem sua matéria-prima, seus recursos, seu 'trabalho produtivo'. Depende de um conhecimento da tradição enquanto 'o mesmo em mutação' e de um conjunto efetivo de genealogias. Mas o que esse 'desvio através de seus passados' faz é nos capacitar, através da cultura, a nos produzir a nos mesmos de novo, como novos tipos de sujeitos. Portanto, não é uma questão do que as tradições fazem de nós, mas daquilo que nós fazemos das nossas tradições. Paradoxalmente, nossas identidades culturais, em qualquer forma acabada, estão à nossa frente. Estamos sempre em processo de formação cultural. A cultura não e uma questão de ontologia, de ser, mas de se tornar. (2003, p. 44 - grifo nosso)

O "lugar" da cultura é um espaço de profundas transformações, em que o homem é capaz de se reinventar, tomando como ponto de partida os diversos processos envolvidos em sua constituição identitária - processos coletivos, em sentido lato ou restrito, processos individuais; processos objetivos ou subjetivos -, que, segundo o próprio Mia Couto, está em constante reformulação, como mecanismo dinâmico e organismo vivo, modificando-se nos contatos histórico que se estabelecem.

A narrativa de Mia Couto e demais escritores africanos - moçambicanos ou não, de expressão em língua portuguesa ou não, mas, em quaisquer dos casos, representantes de vertentes literárias cujo projeto de ficção esteja comprometido com a veiculação do imaginário do "pós"-guerras ou do "pós"-colonial -, permite que se observem os profundos processos de integração cultural, uma vez que, se inscrevendo nas ambiências espaçotemporais dos "pós", mimetiza - em primeiro ou segundo planos da "representação" -, com base nos discursos das personagens, viéses diversificados, ao pôr em contato figuras de origem variada, assimilando-as nas margens - da ficção, da história ou de ambas.

Fala-se de fronteiras híbridas, de identidades mestiças, quando se fala da obra de Mia Couto e de tantos outros seus contemporâneos nas literaturas africanas. Mas como se constroem, no nível da ficção, as personagens em $A$ varanda do frangipani, texto que se tem, aqui, por percurso de leitura? Não há respostas definitivas, mas, no entanto, se podem delinear as margens desses seres de papel -"edifícios de palavras que, por obra e graça da vida ficcional, espelham a vida e fingem tão completamente a ponto de conquistar a imortalidade" (BRAIT, 1985, p. 10) -, indicando suas configurações mnemônicas, as quais se cruzam no "entardecer" de vidas, que não terminam e renascem para outros tempos e novas fronteiras.

As reflexões de um narrador autodiegético, aquele que, na acepção de Gerárd Genette, "relata as suas próprias experiências como personagem central" (REIS; LOPES, p. 259) - o xipoco Ermelindo Mucanga, "revivido" no corpo do inspetor Izidine Naíta, por obra do halakavuma, para "remorrer" e, no novo funeral, passando pelos rituais da terra, ascender a xicuembo -, são entrecortadas, ao longo da narrativa, pelas vozes dos moradores do asilo - abrigo de velhos esquecidos pelo tempo, instalado na velha fortaleza de São Nicolau, sítio cercado, por um lado, de penhascos intransponíveis e, por outro, de praias repletas de minas deixadas ao largo pelas duas guerras, a colonial e a civil. Mucanga e as demais personagens - de múltipla constituição, representantes de diferentes estratos étnico-culturais - encontram-se abandonadas - no sentido mais lato e abrangente do abandono -, em um espaço de conflito, sem terem, sequer, tranquilidade. Eles não esqueceram o passado nem as desgraças por que passaram, pois, comprometidos com a possibilidade de relatar o que experienciaram, mesmo não tendo quem, efetivamente, os ouça (Cf. FONSECA; CURY, 2008, p. 80-81), travam contato com o ontem e o hoje, sendolhes consentido um "re-enchantment of the world" (GARUBA, 2003, p. 265), que se verifica, por exemplo, em suas "confissões" ao inspetor.

A opção por tomar o universo miacoutiano como passível de (re)encantamento é permitida pelo reivindicar, próprio de uma transposição de fronteiras, de um espaço "contra o esquecimento do mundo da oralidade, das histórias contadas pelos mais velhos" (FONSECA; CURY, 2008, p. 81). Tal espaço revela, assim, a constituição múltipla de uma varanda - A varanda do frangipani -, onde as personagens são tão matizadas quanto seu entorno, correspondendo a uma perfeita simbiose semiótica, em que as semioses do tempo, do espaço e das personagens - categorias essenciais à narrativa (Cf. REIS, 2001, 
p. 345-373) - se amalgamam, trocando, entre si, sentidos insólitos. Assim, as estratégias a que Mia Couto recorre emprestam, similarmente, singularidade inaudita a essas categorias ficcionais, implicando, por consequência, o inusitado de grande parte das ações - a quarta categoria a somar-se àquelas.

Refletindo sobre o animismo presente em África, Harry Garuba diz que:

'magical elements of thought' are not displaced but, on the contrary, continually assimilate new developments in science, technology, and the organization of the world within a basically 'magical' worldview. Rather than 'disenchantment,' a persistent re-enchantment thus occurs, and the rational and scientific are appropriated and transformed into the mystical and magical. (2003, p. 267)

O reencantamento apontado por Garuba, tendo como ponto simétrico a convivência entre o racional e o mágico - nas perspectivas por ele assumidas -, com assimilações mútuas, apresenta um processo característico das nações formadas após a independência, ou seja, corresponde às ex-colônias. Cabe, aqui, por ventura, puxar um fio a ser, em outro momento, deslindado e entrelaçado, pois, ao apresentar seu ponto de vista, Garuba permite que se correlacione o animismo de África à maravilha da América Latina, aproximando o real-maravilhoso iluminado por Alejo Carpentier $(1985 ; 1987)$ ao realanimismo subliminarmente sugerido por Pepetela (1989).

Stuart Hall define o processo de hibridismo, próprio dessas novas nações pós-independência - desponta, aqui, mais um "pós", o pós-independência, a unir-se ao póscolonial e ao pós-guerras, sem que se possa esquecer, ainda, de outro pós, a emoldurar esses, que é o pósmodernidade, todos eles em demasiado polêmicos -, não como referência à constituição racial mista de uma população, e, portanto, não marcado, apenas, pelo caráter bioetnológico. Para Hall, o hibridismo:

É realmente outro termo para a lógica cultural da tradução. Essa lógica se torna cada vez mais evidente nas diásporas multiculturais e em outras comunidades minoritárias e mistas do mundo póscolonial. Antigas e recentes diásporas governadas por essa posição ambivalente, do tipo dentro/fora, podem ser encontradas em toda parte. Ela define a lógica cultural composta e irregular pela qual a chamada 'modernidade' ocidental tem afetado o resto do mundo. (2003, p. 74)

É na composição desse hibridismo, de que trata Hall, não marcado pelo caráter autoritário da assimilação que se impõe ao "outro", com rigores e sofrimento, construído a partir de um processo fundamentado na fluidez, que se pode observar a edificação multifacetada da varanda dessa fortaleza colonial - A varanda do frangipani -, espaço em que os universos se imiscuem, e a razão se une aos mitos, às lendas, às crenças, aos ritos e aos rituais, amalgamando os realia aos mirabilia, e viceversa.

Segundo Néstor Canclini, estudioso dos processos de hibridismo na América Latina, o hibridismo se constituiria pela tradução, referindo-se às profundas transformações culturais, derivadas de universos com diferentes formações, possibilitando enfocar os ganhos e as perdas das trocas que se dão no "lugar" da cultura, fronteiras, que se entrelaçam.

A reunião de elementos, observada pelo processo de hibridismo, remete às relações que se estabelecem no interior do asilo de idosos, cenário da narrativa miacoutiana. Os idosos foram levados à velha fortaleza colonial, transformada em abrigo, após as guerras de independência - "São Nicolau", outrora lugar de defesa territorial, a seguir, transformado em prisão, e, em todo o período colonial, utilizado como entreposto de trocas comerciais.

O diretor, Vasto Excelêncio, responsável pelo lugar e pela guarda dos anciões, atuava como um déspota, subvertendo as funcionalidades do espaço, que utilizava como depósito de armamentos, ali mantidos em segredo, na condição de escondido espólio de guerra - os espólios são conjuntos de bens que ficam aos vivos por morte de alguém ou podem, ainda, ser produto da "espoliação" em guerras. Ele também vertia, sobre todos os habitantes do/no asilo, idosos ou não - pois, lá, havia sua esposa, Ernestina, e a enfermeira, Marta Gimo - agruras e sofrimento. O homem, vestido com a máscara do poder, mantinha uma incômoda relação com todos, deixando os idosos relegados à fome e à desatenção, ao utilizar o armazém do asilo como paiol, onde guardava os resquícios das guerras, como um tesouro.

A história começa com o narrador, Ermelindo Mucanga, se apresentando - "Sou o morto. [...] eu faleci junto com meu nome faz quase duas décadas" (COUTO, 2007, p. 9) - e contando, superficialmente, sua morte, seu enterro e sua estada ao pé da frangipaneira, junto de suas raízes, até que, como relata, "um dia, fui acordado por golpes e estremecimentos. Estavam a mexer na minha tumba" (COUTO, 2007, p.11). Precisava-se de um herói e, para tê-lo, buscavam os restos mortais daquele "pequenito carpinteiro" (COUTO, 2007, p. 11).

Sem, ainda, entender o que lhe acontecia, Mucanga consulta o pangolim - mamíferos desdentados vermilingues, de dorso testáceo -, seu bicho de estimação, mamífero que mora com os falecidos, aquele que "tomba na terra para entregar novidades ao mundo, as proveniências do porvir" (COUTO, 2007, p. 13). E o pangolim lhe confidencia que o vão transformar em herói. 
Mucanga, contudo, não consegue ver razão na coisa, e o halakavuma - o halakavuma é um pangolim, animal bem estranho, nunca visto mais de uma vez na mesma região e no mesmo ano, e quando aparece, um grande ritual deve ser realizado, para que assim se possa desvendar a mensagem que o animal traz, havendo casos em que traga mensagem específica para a pessoa que o encontra - lhe informa que ele vai ficar vivo outra vez, para, então, remorrer e se cumprirem os ritos ritualísticos da tradição que lhe foram suprimidos quando de sua primeira morte.

Em sua morte, não the apropriaram o funeral, não recebeu as cerimônias da terra - lugar que habita, como ser de uma nação; lugar para onde se vai, quando se morre, semanticamente conjuminados na relação do significante com os significados -, e, por isso, ficou na condição de xipoco - alma penada que vagueia sem destino; fantasma -, não podendo ascender a xicuembo espírito de antepassado; ser supremo, eterno, sobrenatural e existente por si só. Agora, era, conforme o pangolim lhe explica, sua oportunidade para reviver, remorrer e, aí sim, passar pelos ritos da crença local, conquistando a tranquilidade necessária no mundo dos mortos.

Cabia, ao halakavuma, arranjar-lhe um corpo em que reviver, em que se alojar, tornar à vida. Mas havia de ser um para o qual a morte estivesse certa e próxima. Nada tardou, como admite Mucanga, "nessa mesma noite, eu estava transitando para xipoco. Pelas outras palavras, me transformava num "passa-noite"' (COUTO, 2007, p. 14). Tratava-se de "um 'de fora"' (COUTO, 2007, p. 15), que chegara para investigar a estranha morte do diretor do asilo. Ele se instalava no corpo desse inspetor e "seria certo que morreria" (COUTO, 2007, p. 16), em seis dias - aspecto que aqui não se desenvolverá, mas que merece atenção, é o fato de que "segundo o pensamento judeu, a duração da criação [do mundo] é representada por seis dias [...] [, e] o sétimo dia [...] [tem] por significação representar a vida eterna" (CHEVALIER; GHEERBRANT, 1990, p. 336), o que equivaleria à condição de xicuembo, ser supremo, eterno, a qual Mucanga iria ascender.

Assim, Ermelindo Mucanga saiu das profundezas da terra, onde habitava, morto, ao lado do pangolim, as raízes da frangipaneira, para subir à superfície, animisticamente incorporado no inspetor Izidine Naíta, ambos fadados a morrer em 6 dias, para ele, então, reviver e ter a oportunidade de um enterro segundo os costumes ritualísticos locais. Desse ponto em diante, a narrativa tensionará, polifonicamente, as vozes de diferentes personagens - Mucanga, Naíta, Navaia, Xidimingo, Nhonhoso, Nãozinha, Ernestina, Marta... -, percorrendo a investigação e as descobertas, encontrando-se os fatos que envolveram o assassinato de Excelêncio, e, por fim, Naíta se redescobre como "ser" da terra, além, é claro, de se cumprirem as predições em torno de Mucanga.
Izidine Naíta, inspetor de polícia, chega a São Nicolau para investigar o assassinato de Vasto, "vindo 'de fora", afeito a suas considerações racionais, mas mergulhado num mundo permeado por mistérios e descobertas, demonstrando, aos poucos, seu "olhar estrangeiro", na perspectiva do retornado, tão cara às narrativas de Mia Couto, em que o escritor contrapõe o "de dentro" e o "de fora". Naíta, moçambicano de nascença, estava fora de sua terra natal havia décadas.

Em contraponto à construção da personagem Izidine, pode-se enfocar a personagem Domingos Mourão, o velho português. Ele se rebatizou, em Moçambique, Xidimingo, constituindo-se, como figura narrativa, bem como Naíta, pela oposição entre "o de fora" e "o de dentro". Apesar das fortes semelhanças, deve-se ter atenção às dessemelhanças entre essas personagens, pois, Mourão, além de (re)conhecer os moradores do asilo como companheiros, também, revela:

Lhe conto uma história. [...] Nesse tempo, um velho preto que andava pelas praias a apanhar destroços de navios. Recolhia restos de naufrágios e os enterrava. Acontece que uma dessas tábuas que ele espetou no chão ganhou raízes e reviveu em árvore. Pois, senhor inspector, eu sou essa árvore. Venho de uma tábua de outro mundo mas o meu chão é este, minhas raízes renasceram aqui. (COUTO, 2007, p.46)

Renascer em novas fronteiras, ao modo de uma árvore, com raízes que se fixam a outro e novo solo, permite que se infira um olhar de apropriação, assumido por Xidimingo, personagem que guarda, em si, sua cultura portuguesa, mas, como o texto mesmo informa, com "a gramática toda suja, da cor desta terra" (COUTO, 2007, p.46). O "desapotuguesamento" de Mourão, tal qual a assimilação de Naíta, em seu período de afastamento de Moçambique, revelam traços de identidades que se amalgama(ra)m, formando uma nação de muitas nações, em que os espaços se (entre)cruzam e o tempo (ultra)passa os limites da história, como relata Ermelindo Mucanga:

no buraco da cova, durante a minha morte, eu estive cego por dentro. Não podia ver o meu passado, perdera a lembrança. Não é que estivesse realmente invisual. Era pior ainda. Estava como o cão que perdeu o cheiro. Há coisas que aprendemos para nos longear do bicho que somos. Essas aprendizagens custam tanto que nem delas nos lembramos. (COUTO, 2007, p. 118 - grifo nosso)

Mucanga expõe circunstâncias de seu passado, como morto, e de seu presente, em sua "peregrinação pelo corpo de Izidine" (COUTO, 2007, p. 114), concebendo a vida como uma miragem, que já provara (Cf. COUTO, 2007, p. 114). A perspectiva dessa personagem evoca elementos 
em diálogo, pois ele, como morto, além de pertencer ao passado, é, ainda, parte do presente, revivido. Desse modo, convive com a diversidade do asilo, narrando sua morte ao mesmo tempo em que seu país se libertara da condição de colônia, sem se esquecer de descrever, porque revivido, seu prazer em retornar ao plano dos vivos, com o qual esteve em contato nos últimos vinte anos, desde lá das raízes da frangipaneira, ouvindo as lembranças dos idosos, que, ao pé da árvore, sob sua sombra, rememoravam.

O narrador é, como aquele em quem se hospeda, um ser marcado pelo olhar "de fora", ausente da vida, mas atuante nela a partir de seu próprio olhar. Ermelindo, ao voltar ao mundo dos vivos, se lembra de suas origens e chega a afirmar que:

Esses a que chamavam de 'irmãos' não tinham parentesco comigo. Eram revolucionários, guerrilheiros. Combatiam o governo dos portugueses. Eu não tinha coração nessas makas.Sempre estudara em missão católica. Me tinham calibrado os modos, acertadas as esperas e as expectativas. Me educaram em língua que não era materna. Pesava sobre mim esse eterno desencontro entre palavra e ideia. (COUTO, 2007, p. 114 - grifo nosso)

Ele destaca, assim, as fronteiras existentes entre o colonizador e o colonizado; porém, como um assimilado, revela-se em "eterno desencontro", não compreendendo nem aqueles que o chamavam de "irmão", nem os que "calibraram seus modos".

Mucanga remete-se, pouco a pouco, ao conflito de conviver com o halakavuma, na cova em que estava, sendo um xipoco, e conhecer, na vida, seu medo, sua apatia em não lutar para conseguir entrelaçar "palavra e ideia", formulando, não mais, suas dúvidas, mas a confirmação de suas fronteiras híbridas, que necessitavam se reunir para construir as novas identidades de seu "eu". Trata-se de um ser insólito em sua constituição, sem pertencer ao mundo dos vivos e sem lugar de permanência entre os mortos, já que seu túmulo fora revolvido na busca por se forjar um herói, descrita por sua falsidade - a cena da nação precisava da encenação de um herói nacional.

O xipoco não era um herói, ao contrário, morrera, segundo ele, desconhecendo as relações que embasam a vida, como, por exemplo, amor ou desejo, nutrido por Marta Gimo. Vivendo entre dois planos harmoniosos, ele não se considera digno de se tornar herói, mesmo consciente de sua capacidade de transitar entre fronteiras diversas, pois é convivente no hoje e conhecedor do ontem, assimilado, mas dependente dos elementos de sua formação.

Refletindo sobre a constituição dessa personagem, repleta de elementos híbridos, a começar por sua confi- guração, desde o início até o final da narrativa, como duplo - Mucanga/Naíta; Morto/Vivo; Herói/Desconhecido -, pode-se, aqui, buscar socorro junto a Liv Sovik, quando este estabelece considerações sobre a Diáspora e afirma que Hall "pensa a África como elemento que sobreviveu e como meio de sobrevivência na diáspora, defende a hibridização ou 'impureza' cultural enquanto a 'forma em que o novo entra no mundo"" (2003, p. 19). Mucanga é um sobrevivendo às avessas, vivendo relações impuras, antes da primeira morte e durante a segunda vida. Ele é híbrido, principalmente porque duplo. E as formas como entra nos mundos dos mortos ou dos vivos denunciam suas impureza e hibridez, deformação e relações.

Nesse sentido, o hibridismo "intercultural" representaria um fenômeno de amálgama cultural, que promoveria a "dialogicidade heterogénea" (AFONSO, 2007, p. 549), em que há a dissolução ou permeabilização das fronteiras entre as partes envolvidas nas trocas. Percebe-se, portanto, que a hibridação se compõe do contato entre universos distintos, constituindo culturas multifacetadas, plurais, diversas.

Mucanga divide com Naíta não apenas seu corpo, mas, também, traços subjetivos de retorno à cultura. $\mathrm{O}$ inspetor se revela muito mais marcado por suas escolhas, afinal, é um retornado, ou seja, aquele que, após um longo período distanciado de suas origens, encontra dificuldades para se adaptar novamente aos costumes de seu povo. Izidine era um mezungo - "um branco, um de fora, um que não merece confianças", apesar de preto, como os demais moradores do asilo (COUTO, 2007, p. 52)-e, por conseguinte, tinha dificuldades em estar aberto às suas origens e a ver e ouvir, como avisa Mia Couto, "o ser de um continente que ainda escuta [...] trouxe um estar mais atento a essas outras coisas que parecem estar além da ciência. Não temos que acreditar nessas 'outras coisas'. Temos apenas que estar disponíveis” (COUTO, 2005, p. 123 - grifo nosso).

Izidine, buscando na racionalidade as respostas para o mundo do asilo, é colocado em confronto com o desconhecido, pois os moradores do asilo não the têm confiança, devido ao seu afastamento há décadas - como se pode depreender, por exemplo, das reflexões do narrador, ao afirmar que "aquele não era o seu mundo" (COUTO, 2007, p. 40), uma vez "ele estudará na Europa, regressara a Moçambique anos depois da Independência. Esse afastamento limitava o seu conhecimento da cultura, das línguas, das pequenas coisas que figuram a alma de um povo" (COUTO, 2007, p.41-42); das observações de Xidimingo: "[...] o senhor é um mezungo, um branco como eu" (COUTO, 2007, p. 52 - grifo do original); da constatação de Marta: “- Eles todos estão a lhe dizer coisas importantes. Você é que não fala a lingua deles. [...] falam outra língua, outro português" (COUTO, 2007, 
p. 73 - grifo do original); das palavras de Nãozinha: “[...] você, mesmo sendo preto,é lá da cidade. Não sabe nem resposta" (COUTO, 2007, p. 77 - grifo do original). Todavia, todos desejam que ele reconheça aquilo que o constituiu originariamente, mas que, com o decorrer do tempo, fora por ele esquecido, como se percebe, ao final, no diálogo que tem com Marta Gimo:

Marta parecia inclinada a poesias. Disse que a luz é mais leve que a água, seus reflexos ficam boiando como peixes lunares, algas de fogo.

- São assim também as memórias destes velhos flutuando mais leves que o tempo.

Um volume estranho no vestido chamou a atenção do inspector. Retirou o chumaçudo objecto: era uma escama. Mostrou-a à enfermeira.

- Sabe o que é isto?

- Isso, caro inspector...

- Me chame de Izidine.

- Isto, Izidine, é uma escama de pangolim, o halakavuma.

- Ah, já sei. Esse que desce das nuvens para anunciar noticias do futuro?

- Afinal você não esqueceu a tradição. Vamos ver se esqueceu outras coisas. (COUTO, 2007, p. 96-97 grifo do original)

Vê-se, assim, que se tratava apenas de um esquecimento, de uma ausência de memória, posto que, justamente no clímax narrativo, Izidine se lembra de quem são as escamas encontradas no pátio da varanda. São daquele ser mítico-mágico, responsável, no nível da diegese - termo aqui empregado, conforme Genette, "para designar o universo espácio-temporal no qual se desenrola a história" (REIS; LOPES, 2002, p. 107) -, pelo retorno de Mucanga ao mundo dos vivos. Ele é o mensageiro entre os dois mundos - dos vivos e dos mortos - e elo de ligação entre os dois planos da história narrada.

"Assimilados", "moçambicanizados", por fim, adaptados à cultura do "outro", quer por imposição, quer por contato natural, o homem pode optar entre ser "branco" ou "negro", isto é, "maculado" por uma escolha de raça, de linguagem, ou valoração cultural. A reunião de traços culturais lhe permite "trocas de almas" ou "caminhar por todas as margens", conhecendo e se reconhecendo em suas múltiplas relações.

É nesse sentido que se pode deixar, um pouco, Izidine Naíta e Ermelindo Mucanga, assimilados pela cultura do dominador, e focar Domingos Mourão, o velho português, "assimilado às avessas", embebido pela cultura do dominado - para ele, "dominador", se se entende a relação em um plano primeiro e mais direto, de agente e paciente, de produtor e produto, de dominador e dominado, de sobrepujante e sobrepujado. É como se essa assimilação às avessas o retornasse à vida, mesmo velho, mais envolvido entre os outros mais velhos; mesmo largado no/do tempo da história.

Assim, nota-se que os elementos da cultura do colonizado, em $A$ varanda do frangipani, se impõem, e não se consegue distinguir nitidamente quem assimila quem, já que o "colonizador [, por vezes, é] tão presa da estereotipia quanto o colonizado" (FONSECA; CURY, 2008, p. 71), seduzido pelo diferente - estereótipo, exótico, estranho, maravilhoso. $\mathrm{O}$ desconhecido passa a conhecido, como se pode percebe nas palavras de Domingos Mourão: "Resta-me só este espaçozito em que me sombreio de mar. Minha nação é uma varanda" (COUTO, 2007, p. 47 - grifo nosso). Para ele, agora rebatizado Xidimingo por afeto naquela terra, ali era o lugar em que se recriavam seus sonhos, onde não havia barreiras raciais ou imposições culturais, tendo como ponto de partida e chegada os cruzamentos culturais variados, que só têm a engrandecer a micronação inventada no interior do asilo: mosaica, híbrida, plural, multifacetada...

Logo, tem-se, nesse cenário, uma micronação, formada por um grupo marcado por diversidades, com europeus e africanos, portugueses e moçambicanos, brancos e negros, homens e mulheres. Espaço cuja marca mais premente é a heterogeneidade, tanto física, quanto cultural. Nesse pequeno grupo - fechado, de lado, como já se observou, pelos penhascos inacessíveis voltados para o mar; por outro, pelas areias da praia repletas de minas deixadas desde o tempo das guerras -, as trocas, oriundas das crenças na magia da terra, se manifestam de modos diversos: nos cheiros emanados das flores da frangipaneira, nas feitiçarias de Nãozinha, nas escamas do pangolim, enfim, na própria construção memorialística da narrativa, que aponta para a (re)invenção de lugares e pessoas.

Opositivamente, pode-se perceber a relação híbrida da situação existente entre Mourão e Naíta, porque ambos se misturam com traços diversos, trocando, em diálogos, experiências. Mas os pontos de partida dos dois são diferentes. Enquanto Izidine, filho da terra, reencontra sua crença e se envolve com a magia emanada no asilo; Mourão, português de nascença, almeja apenas permanecer junto à frangipaneira, que lhe embala o sentimento de passar o tempo (Cf. COUTO, 2007, p. 45). No entanto, deve-se observar que a intersecção de suas vidas ocorre, exatamente, pela presença da maravilha, do encantamento, que despe os olhares "de fora", estranhamente pertencentes a Naíta, "o de dentro", e ao português, "o de fora", permutando, entre si, os lugares semelhantes e, ao mesmo tempo, dessemelhantes, que ocupam no seio da ficção miacoutiana. Domingos Mourão, acaba Xidimingo, semeado por seus amigos e moradores do asilo, como ele, que têm por última habitação e sossego (Cf. COUTO, 2007, p. 46). 
Dessa forma, pode-se observar que a própria história - "plano dos conteúdos narrados" (REIS; LOPES, 2002, p. 111) - extrapola limites, subvertendo o que seria mais comum, uma vez que cria a imagem de um retornado, desconhecedor de suas origens, dividindo espaço com um português, renascido simbolicamente em sua nova morada.

Apropriando-se do que aponta Jane Tutikian sobre a constituição da identidade em nações de Língua Portuguesa, é possível afirmar que, "na obra de Mia Couto, $[. .$.$] a representação mítica gera a afirmação de$ uma identidade cultural que transgride uma identidade racional, a européia, imposta pelo colonialismo" (TUTIKIAN, 2006, p.60). Esses conflitos de fronteira, que se questionam, e a concepção de uma imagem difusa entre colonizador e colonizado, que se depreende, são, conforme Fonseca e Cury, "estratégias para a apreensão dos diferentes processos de negociação, de misturas, de hibridismos presentes nos romances de Mia Couto, [podendo] [...] ser teoricamente iluminada pelas referências ao chamado realismo mágico, ao real maravilhoso" (2008, p. 121).

O passado e o presente se misturam, nessa narrativa, ao mesmo tempo, para compor um "entre-lugar", que assim se pode "traduzir", recorrendo-se às palavras de Homi Bhabha, quando ele observa que:

O trabalho fronteiriço da cultura exige um encontro com 'o novo' que não seja parte do continuum de passado e presente. Ele cria uma ideia do novo como ato insurgente de tradução cultural. Essa arte não apenas retoma o passado como causa social ou precedente estético; ela renova o passado, refigurando-o como um 'entre-lugar' contingente, que inova e interrompe a atuação do presente. (2003, p. 27)

E esse "entre-lugar" se constitui a partir de espaços diferentes, como ocorre, inclusive, com as personagens de $A$ varanda do frangipani.

Como produto desse processo de elaboração narrativa, a maravilha irrompe desde o início, em um cenário circundado de realidades - as guerras, as minas, a opressão -, representada, precipuamente, pela personagem-narrador e, ainda, pela intervenção de um ser mítico, o halakavuma, capaz de subjugar a morte, fazendo parte de dois planos intercomunicantes, para os quais, de certa maneira, transporta Ermelindo Mucanga.

Nesse sentido, "a autonomia da obra diante do real é a ruptura da causalidade realista, quando, por suas próprias transfigurações, a irrealidade começa a adquirir existência" (JOZEF, 2006, p. 166). Segundo identifica Maria Fernanda Afonso, o irreal toma o real e reúne traços da racionalidade contemporânea em diálogo com: a intervenção de forças mágicas que contrariam os humanos, o realismo mágico invade o espaço textual, facilitando o entendimento entre os mortos e os vivos, $o$ visivel e o invisivel, o concreto e o transcendente, tornando-se um instrumento particularmente apto em denunciar a fragilidade das comunidades arcaicas expostas aos males que afligem as sociedades póscoloniais. (2007, p. 552 - grifo nosso)

Nessa perspectiva de leitura, a composição narrativa de Mia Couto apresenta um olhar multifacetado e característico de espaços conflituosos, formulando-se a partir de olhares diversos, que se cruzam pelas misturas derivadas de seu contato. Assim, pode-se notar a irrupção do insólito ficcional em narrativas de caráter autóctone, em uma clara atitude contra-hegemônica - dando voz e vez aos esquecidos, mesmo que inconscientemente (Cf. FONSECA; CURY, 2008) -, o que faz trazendo, ao centro da narrativa, representações de outro plano de significação, nutrido pelo animismo telúrico. Tal animismo se pode, sem risco de errar, apresentar-se, observando o discurso de Mia Couto em seus textos de opinião, quando ele adverte que:

A concepção relacional da identidade, inscrita no provérbio: 'Eu sou os outros'; a ideia de que a felicidade se alcança não por domínio mas por harmonias; a ideia de um tempo circular; o sentimento de gerir o mundo em diálogo com os mortos: todos estes conceitos constam da rica cosmogonia rural africana. (COUTO, 2009, p. 108-109 - grifo nosso)

O provérbio citado pelo moçambicano remete às reflexões humanas, constatando a ideia da felicidade encontrada no e pelo "outro". A formação da identidade, nesse sentido, se constituiria a partir do exemplo ou da relação com os "outros", portanto, em uma atitude coletiva. É com base na contribuição social, do contato e da troca, que se pode perceber o propósito de Mia Couto ao afirmar a cosmogonia rural africana como rica. A riqueza, que fundamenta o argumento miacoutiano, é encontrada na origem dos cultos anímicos, que (con)vivem na cultura, pois a referência ao tempo, o envolvimento do homem com a natureza ao cultuar seus mortos, seriam, por conseguinte, margens de crenças que (ultra/per)passam a descrença racional.

$\mathrm{O}$ animismo, evocado pela referência de Mia Couto, poderia ser caracterizado, tal qual a crença do povo, por um hibridismo fundamentado nas diversas influências vividas pelo homem no tempo, na vida. Tal hibridismo não se dá, porém, apenas no campo da crença e dos cultos anímicos de origem, mas ainda, em clara denúncia, presente em sua ficção, nas relações de retomada de marcas de um gênero, talvez por apropriação de seus traços, que é o realmaravilhoso, apropriado desde a América Latina. 
Tornando a Bhabha, vale lembrar, com recurso às suas palavras, que "é sempre em relação ao lugar do Outro que o desejo colonial é articulado" (2003, p.76), pois o colonizado é alguém capaz de colonizar, já que os limites das trocas culturais inexistem, principalmente quando o possível dominado mantém sua cultura, apesar da imposição do "outro". E, em A varanda do frangipani, esses papéis são permutáveis nas figuras de Izidine Naíta e Ermelindo Mucanga, conduzidas ou construídas pela voz do xipoco Ermelindo Mucanga, personagem-narrador, em função assumidamente autodiegética.

As fronteiras do mundo elaborado por Mia Couto, nesse texto, são híbridas, marcadas por profundas trocas de almas, que se consolidam na irrupção do insólito ficcional, gestado às próprias margens da narrativa. Ao submeter as personagens ao convívio com um morto, revivido por meio de um ritual invertido, aparentemente típico da terra, portanto, anímico, o autor convida à apreensão de um mundo de união entre os realia e os mirabilia, aproximando-se, por apropriação e resgate, do real-maravilhoso - para Garuba (2003), menos abrangente que o real-animista -, por estabelecer, num processo de trocas harmoniosas entre o sólito e o insólito, a reunião de elementos diversos, que produzem profundos diálogos, capazes de produzir trânsitos entre a morte e a vida, o passado e o presente.

\section{Referências}

AFONSO, Maria Fernanda. O conto moçambicano: escritas pós-coloniais. Lisboa: Caminho, 2004.

AFONSO, Maria Fernanda. A problemática pós-colonial em Mia Couto: mestiçagem, sincretismo, hibridez, ou a reinvenção das formas narrativas. In: NÓBREGA, José Manuel da; MOTA, Nano Pádua de (Ed.). Estudos de Literaturas Africanas - Cinco povos, cinco nações. Atas do Congresso Internacional de Literaturas Africanas de Língua Portuguesa. Coimbra: Novo Imbondeiro, 2007. p. 546-553.

BHABHA, Homi K. O local da cultura. Belo Horizonte: EdUFMG, 2003.

BRAIT, Beth. A personagem. Série Princípios. São Paulo: Ática, 1985.

CANCLINI, Néstor García. Culturas híbridas: estratégias para entrar e sair da modernidade. 4. ed. São Paulo: EdUSP, 2008.

CARPENTIER, Alejo. Prefácio. In: O reino deste mundo. Rio de Janeiro: Record, 1985. (Mestres da Literatura Contemporanêa).

CARPENTIER, Alejo. A literatura do maravilhoso. São Paulo: Vértice, 1987.
CHEVALIER, Jean; GHEERBRANT, Alain. Dicionário de símbolos. 3. ed. Rio de Janeiro: José Olympio, 1990.

COUTO, Mia. Pensatempos - Textos de opinião. 2. ed. Lisboa: Caminho, 2005.

COUTO, Mia. O último voo do flamingo. São Paulo: Companhia das Letras, 2005a.

COUTO, Mia. A varanda do frangipani. São Paulo: Companhia das Letras, 2007.

COUTO, Mia. E se Obama fosse africano? E outras interinvenções. Lisboa: Caminho, 2009.

COUTO, Mia. Pensageiro frequente. Lisboa: Caminho, 2010.

COUTO, Mia. Entrevista concedida a MARTINS, Celina. $O$ estorinhador Mia Couto. A poética da diversidade. Madeira: abril de 2002. Disponível em: <http://www.revistabrasil.org/ revista/artigos/celina3.html > . Acesso em: 21 maio 2010.

FONSECA, Maria Nazareth Soares; CURY, Maria Zilda Ferreira. Mia Couto: espaços ficcionais. Belo Horizonte: Autêntica, 2008.

GARUBA, Harry. Explorations in Animist Materialism: Notes on Reading/Writing African Literature, Culture, and Society. In: Public Culture, v. 15, n. 2, p. 261-285, Spring 2003. Disponível em: <http://muse.jhu.edu/journals/public_culture/ toc/pc15.2.html>. Acessado em: 28 mar. 2012.

HALL, Stuart. Da diáspora: identidades e mediações culturais. Belo Horizonte: Editora UFMG; Brasília: Representação da UNESCO no Brasil, 2003.

JOZEF, Bella. A máscara e o enigma. Rio de Janeiro: Francisco Alves, 2006.

PEPETELA, Arthur Pestana. Lueji - o nascimento de um império. Porto, Portugal: União dos Escritores Angolanos, 1989.

REIS, Carlos. O conhecimento da literatura. Introdução aos estudos literários. 2. ed. Coimbra: Almedina, 2001.

REIS, Carlos; LOPES, Ana Cristina. Dicionário de narratologia. 7. ed. Coimbra: Almeida, 2002.

SOVIK, Liv. Apresentação - Para ler Stuart Hall. In: HALL, Stuart. Da diáspora: identidades e mediações culturais. Belo Horizonte: Editora UFMG; Brasília: Representação da UNESCO no Brasil, 2003.

TUTIKIAN, Jane Fraga. Mia Couto: uma criação universal para uma identidade nacional. In: Velhas identidades novas - o póscolonalismo e a emergência das nações de língua portuguesa. Porto Alegre: Sagra-Luzzatto, 2006. p. 57-88.

Recebido: 27 de setembro de 2013. Aprovado: 6 de dezembro de 2013 Contato: luciana.silva.235@gmail.com flavgarc@gmail.com 